\title{
Proteomic Analysis Reveals Suppression of Bark Chitinases and Proteinase Inhibitors in Citrus Plants Affected by the Citrus Sudden Death Disease
}

\author{
M. D. Cantú, A. G. Mariano, M. S. Palma, E. Carrilho, and N. A. Wulff
}

First and fourth authors: Instituto de Química de São Carlos, Universidade de São Paulo, São Carlos, SP, Brazil; second and fifth authors: Fundecitrus, Fundo de Defesa da Citricultura, Araraquara, SP, Brazil; and third author: Instituto de Biociências de Rio Claro, Universidade Estadual Paulista, Rio Claro, SP, Brazil.

Accepted for publication 3 June 2008.

\begin{abstract}
Cantú, M. D., Mariano, A. G., Palma, M. S., Carrilho, E., and Wulff, N. A. 2008. Proteomic analysis reveals suppression of bark chitinases and proteinase inhibitors in citrus plants affected by the citrus sudden death disease. Phytopathology 98:1084-1092.

Citrus sudden death (CSD) is a disease of unknown etiology that greatly affects sweet oranges grafted on Rangpur lime rootstock, the most important rootstock in Brazilian citriculture. We performed a proteomic analysis to generate information related to this plant pathogen interaction. Protein profiles from healthy, CSD-affected and CSD-tolerant stem barks,

proteins on 2-DE gels made it possible to distinguish healthy barks from CSD-affected barks. Protein spots with MW around $30 \mathrm{kDa}$ and $\mathrm{pI}$ values ranging from 4.5 to 5.2 were down-regulated in the CSD-affected rootstock bark. This set of protein spots was identified as chitinases. Another set of proteins, ranging in pI from 6.1 to 9.6 with an MW of about 20 $\mathrm{kDa}$, were also suppressed in CSD-affected rootstock bark; these were identified as miraculin-like proteins, potential trypsin inhibitors. Downregulation of chitinases and proteinase inhibitors in CSD-affected plants is relevant since chitinases are well-known pathogenesis-related protein, and their activity against plant pathogens is largely accepted.
\end{abstract} were generated using two-dimensional gel electrophoresis. The protein spots were well distributed over a pI range of 3.26 to 9.97 and a molecular weight (MW) range from 7.1 to $120 \mathrm{kDa}$. The patterns of expressed
Additional keywords: plant proteomics.
In 2001, the outbreak of a new citrus disease called citrus sudden death (CSD), which affects sweet oranges grafted on Rangpur lime plants, became a threat to the Brazilian citrus industry $(16,38)$. Rangpur lime is the most prevalent rootstock in Brazil, and it is employed in about $85 \%$ of the 200 million citrus trees in São Paulo and Minas Gerais states, the largest citrus area in Brazil, which is responsible for more than $53 \%$ of the world citrus juice trade. CSD canopy symptoms are not specific, but they have the following typical characteristics: leaves become pale and yellow-green; the trees also show partial defoliation and have fewer new shoots than usual or even no internal shoots, which may culminate in the death of the tree (1). This behavior is related to rootstock phloem degeneration in the bud-union region, and the most specific symptom of the disease seems to be the yellow discoloration in the rootstock bark $(16,38)$ (Fig. 1). Plants with CSD symptoms show aggregation at relatively low incidence; this pattern is suggestive of the action of a vector, as in the case of Citrus tristeza virus (CTV), which is vectored by Toxoptera citricida (1). Recent surveys estimate that more than 4 million citrus trees have been lost to CSD (2).

CSD is a bud-union disease that resembles CTV in its symptoms, epidemiological characteristics (1), and anatomical features (38). CSD has been found to be graft-transmissible (49), but it remains a disease of unconfirmed etiology. Several attempts have been made to discover CTV variants associated with CSD $(1,11$, 17,25,26,37). All such studies used canopy and bark symptoms as detection criteria, but they failed to identify CTV strains that were

Corresponding author: N. A. Wulff; E-mail address: nelsonwulff@ fundecitrus.com.br

doi:10.1094/PHYTO-98-10-1084

(c) 2008 The American Phytopathological Society associated with CSD symptoms. Román et al. (38) also used the criterion of the yellowing of rootstock bark as a diagnostic test of CSD-affected trees to make the claim that CSD is a bud-union disease and to characterize the pathological anatomy. More recently, the impact of CSD damage to fruit production and quality was assessed in a study (3) that also took visual symptoms into consideration. In 2005, a new member of the genus Marafivirus (Tymoviridae) was discovered in a search for a CTV variant in citrus plants suffering from CSD; it was characterized and named Citrus sudden death-associated virus (CSDaV) (25). The first report of a Tymoviridae virus infecting citrus was made in 2002, when RNA with high similarity to Oat blue dwarf virus (OBDV, genus Maculavirus) was described; it shared some characteristics of $\mathrm{CSDaV}$, and it was reported to occur in citrus in the United States (19). To date, it has still not been demonstrated that CSDaV is, in fact, the etiological agent of the disease since Koch's postulates have not yet been fulfilled. CTV has been endemic to Brazil since the late 1930s, and mild CTV isolates have been employed as cross-protecting agents in a strategy to protect against CTV; all citrus plants in the field thus harbor CTV. Although all plants infected by CSDaV are co-infected by CTV, to date, no reports of a single inoculation of $\mathrm{CSDaV}$ causing CSD have been made. This implies that CSDaV may not be solely implicated in CSD etiology, as was already pointed out by Maccheroni et al. (25). Taking all these factors into consideration, we chose to rely most on symptoms as a diagnostic test, namely, the yellowing of rootstock bark associated with the canopy symptom, in order to confirm whether a citrus tree of sweet orange scion grafted on a Rangpur lime rootstock is suffering from CSD.

The proteomic approach involves studying protein content, including the identification of the amino acid sequence of the protein, evaluation of possible post-translational modifications (PTM), 
and further assignment to functional pathways in the cell. Usually, classical proteomic studies are performed by comparative analysis of proteins expressed by an organism under different conditions (e.g., healthy versus disease-affected individuals). Two-dimensional gel electrophoresis (2-DE) is a widely used method in proteomics because it generates a map of proteins that reflects changes in protein expression levels, isoforms, or PTMs. It also permits further structural analysis of isolated proteins by various mass spectrometry approaches (18). Matrix-assisted laser desorption and ionization coupled with tandem time of flight mass spectrometry (MALDI-TOF/TOF) analysis (46) of enzymatically cleaved peptides generates a peptide mass fingerprint (PMF) and tandem MS (MS/MS) fragmentation spectra of selected peptides, thereby enabling protein identification by dedicated software analysis (32). The great advantage of using proteomics to study plantpathogen interactions is that it permits a focus on the interaction of two agents at the same time during the course of an infection.

Using the resolving power of 2-DE, we analyzed citrus bark in the search for clues about the biochemical status of diseased plants. Since rootstock bark is the plant organ that shows the conspicuous symptom of CSD (the yellow staining) (38) (Fig. 1), we analyzed protein extracted from the stem bark in the budunion region.

\section{MATERIALS AND METHODS}

Plant samples. Citrus stem bark was sampled in 2004 from plants in commercial groves. The scion-rootstock combination that was susceptible to CSD (Rangpur lime grafted with 'Valencia' Sweet orange) was obtained from 9-year-old orchards, and tolerant combinations (Tahiti lime over Rangpur lime or Sweet orange over Cleopatra mandarin) were from 8- or 18-yearold orchards, respectively.

Bark samples were collected from five plants from each orchard described in Table 1. Healthy citrus trees were from a CSD-free area. CSD-symptomatic trees were from a grove affected by CSD in the endemic area. From the same CSD-affected grove, symptomless samples were also collected from plants without visible symptoms, found in the vicinity of affected plants (38). In addition, samples from a tolerant scion-rootstock combination were collected from the CSD endemic area. The location of epidemics is according to published data (1,38; Gavião Peixoto is a municipality adjacent to Araraquara and Matão, $200 \mathrm{~km}$ from Frutal, $\mathrm{MG}$, and it is free of CSD). For scion (Sweet orange stem bark) and rootstock (Rangpur lime stem bark), the study had three treatments with five replicates each: healthy, CSD-affected, and CSD-tolerant.

The following CSD-tolerant citrus plants were used as controls: Tahiti lime grafted on Rangpur lime (i.e., CSD-tolerant rootstock control) and 'Valencia' sweet orange grafted on Cleopatra mandarin (i.e., CSD-tolerant scion control) were collected in CSDaffected areas and used as controls for rootstock and scion, respectively (38), since these scion-rootstock combinations do not develop CSD symptoms. CSD-tolerant plants seem to be good controls since they are grown in the same soil and climatic conditions as the CSD-affected plants and under the same vector and pathogen pressure (49); however, they do not develop symptoms (1), not even microscopic ones (38). Symptomless plants from the CSD-affected region cannot be used as controls since at the sampling date (2004), there were no records addressing the pathogenic agent causing CSD; thus, healthy citrus samples were collected far away from the CSD epidemics.

A section $2 \mathrm{~cm}$ in width and $10 \mathrm{~cm}$ in height spanning the budunion line was excised from each plant. After washing the sample with tap water, the tissue was dried with paper towels and stored at $-80^{\circ} \mathrm{C}$. Barks from rootstock and scions were excised and analyzed separately (five plants for each treatment). Samples were ground in liquid nitrogen in a cryogenic mill (Freezer/Mill 6750
SPEX CertiPrep, Metuchen, NJ). Three grinding cycles of 3 min each were applied in order to obtain a fine homogeneous powder.

Rootstock random amplified polymorphism DNA analysis. Total DNA from rootstock bark samples was extracted (12), spectrophotometrically quantified and employed in random amplified polymorphism DNA (RAPD) analysis. To be sure on the nature of rootstock samples analyzed, samples collected as Rangpur lime and Cleopatra mandarin had their RAPD profiles compared (9) with the most common rootstock used by Brazilian citrus growers: Rangpur lime, Volkamerian lemon, Cleopatra Mandarin, sour orange (C. aurantium L.), P. trifoliate, citrumelo Swingle, and Sunki mandarin. RAPD primers were Operon RAPD 10-mer set (Alameda, CA) and polymerase chain reaction (PCR) was carried out in 25- $\mu \mathrm{l}$ reaction consisting of $100 \mathrm{ng}$ of DNA, $0.2 \mathrm{mM}$ dNTPs, $0.4 \mu \mathrm{M}$ primer, $3 \mathrm{mM} \mathrm{MgCl}_{2}$ in $20 \mathrm{mM}$ Tris- $\mathrm{HCl}, \mathrm{pH} 8.4,50 \mathrm{mM} \mathrm{KCl}$, and $1 \mathrm{U}$ of Taq polymerase from Invitrogen. Amplification was performed in an Eppendorf Mastercycler (Hamburg, Germany) after an initial $4 \mathrm{~min}$ denaturation step at $94^{\circ} \mathrm{C}$, which was followed by 36 cycles of 2 min denaturing at $92^{\circ} \mathrm{C}, 1 \mathrm{~min}$ annealing at $37^{\circ} \mathrm{C}$ and 2 min extension at $72^{\circ} \mathrm{C}$. A final extension step of $6 \mathrm{~min}$ at $72^{\circ} \mathrm{C}$ was taken. PCRamplified DNA was visualized under UV light after electrophoresis in $1.4 \%$ agarose in $40 \mathrm{mM}$ Tris- $\mathrm{HCl}, 40 \mathrm{mM}$ acetic acid, and $1 \mathrm{mM}$ EDTA. DNA amplicons profiles were visually compared after gel image capture and rootstock origin was determined from this comparison.

Protein extraction. One gram of ground bark and $50 \mathrm{mg}$ of polyvinylpolypyrrolidone (PVPP) were mixed and used for protein extraction with $5 \mathrm{ml}$ of $50 \mathrm{mM}$ Tris- $\mathrm{HCl}, \mathrm{pH} \mathrm{8.9,} \mathrm{containing}$ $4 \mathrm{mM}$ PMSF, 5\% sodium dodecyl sulfate (SDS), and 15\% glycerol. After gentle stirring, dithiothreitol (DTT) was added to a final concentration of $100 \mathrm{mM}$, and the mixture was centrifuged for $20 \mathrm{~min}(11,000 \times g)$ at $4^{\circ} \mathrm{C}$. The supernatant was set aside, and the pellet was again extracted with $3 \mathrm{ml}$ of the same buffer and centrifuged. Both supernatants were subjected to precipitation with three volumes of iced acetone with $0.07 \%$ (vol/vol) $\beta$-mercaptoethanol, and stored for $2 \mathrm{~h}$ at $-80^{\circ} \mathrm{C}$. The acetone-aqueous extract was centrifuged for $15 \mathrm{~min}(5,000 \times g)$ at $4^{\circ} \mathrm{C}$. The pellet was washed twice with $80 \%$ (vol/vol) acetone containing $0.07 \%$ $\beta$-mercaptoethanol and washed twice more with iced acetone containing $0.07 \% \beta$-mercaptoethanol. The pellets were dried and dissolved in $1.5 \mathrm{ml}$ of buffer containing $7 \mathrm{M}$ urea, $2 \mathrm{M}$ thiourea, $4 \%$ CHAPS, and $50 \mathrm{mM}$ DTT in $5 \mathrm{mM}$ Tris, $\mathrm{pH} \mathrm{8.9.} \mathrm{The} \mathrm{protein}$ concentration of the final supernatant was measured using bovine serum albumin (fraction V) as a protein standard (5). All protein extracts were stored at $-80^{\circ} \mathrm{C}$.

2-DE and image analysis. IPG strips $(13 \mathrm{~cm})$ (GE Healthcare, Little Chalfont, UK) were hydrated for $14 \mathrm{~h}$ with $700 \mu \mathrm{g}$ of protein extract dissolved in $7 \mathrm{M}$ urea, $2 \mathrm{M}$ thiourea, 4\% CHAPS (wt/vol), bromophenol blue (BPB) $0.002 \%$ (wt/vol), and $50 \mathrm{mM}$ DTT at room temperature. The IEF of 3 to 10 immobilized $\mathrm{pH}$ gradient (IPG) strips was performed for $30 \mathrm{~min}$ at $200 \mathrm{~V}, 30 \mathrm{~min}$ at a gradient from 200 to $1,000 \mathrm{~V}, 2.5 \mathrm{~h}$ at a gradient from 1,000 to $8,000 \mathrm{~V}$, and then at $8,000 \mathrm{~V}$ until a total of $20 \mathrm{kVh}$ was reached. The isoelectric focusing (IEF) of 4 to 7 IPG strips was as follows: $30 \mathrm{~min}$ at $200 \mathrm{~V}, 90 \mathrm{~min}$ at a gradient from 200 to $1,000 \mathrm{~V}, 3 \mathrm{~h}$ at a gradient from 1,000 to $8,000 \mathrm{~V}$, and then $8,000 \mathrm{~V}$ until a total of $20 \mathrm{kVh}$. Focused strips were equilibrated using a first incubation step in equilibration buffer $(50 \mathrm{mM}$ Tris- $\mathrm{HCl}$, $\mathrm{pH}$ 8.9, $6 \mathrm{M}$ urea, 30\% glycerol [vol/vol], SDS 2\% [wt/vol], $0.002 \%$ BPB [wt/vol) containing $100 \mathrm{mM}$ DTT for $15 \mathrm{~min}$, followed by another $15 \mathrm{~min}$ incubation step in the same equilibration buffer containing $250 \mathrm{mM}$ indole-3-acetic acid (IAA) instead of DTT.

The second dimension was performed on a $12.5 \%$ polyacrylamide SDS gel (Tris-glycine system; $20 \times 20 \mathrm{~cm}$ ) for IPG strips 3 to 10 (24). Tris-tricine $10 \%$ polyacrylamide SDS gels were employed for IPG strips 4 to 7 (41) using the Protean II system 
(Bio-Rad, Hercules, CA). The BenchMark protein ladder from Invitrogen (Carlsbad, CA) was used as the molecular weight marker on all gels.

After SDS-polyacrylamide gel electrophoresis (SDS-PAGE) electrophoresis (run at $4^{\circ} \mathrm{C}$ ), gels were stained by $\mathrm{CBB}$ colloidal staining (6). The stained gels were scanned (all gels with the same parameters for intensity, brightness, and contrast) and analyzed using ImageMaster 2D Software (GE Healthcare). Each treatment (healthy, CSD-affected, and CSD-tolerant) group included the analysis of five plants with reproducible and high quality 2-DE gel patterns for each IPG range (five replicas for each treatment in pI 3 to 10 and five replicas in $\mathrm{pI} 4$ to 7). ImageMaster 2D was used to measure spot volume from selected spots and to compare gel patterns between groups. The average value of five replicates followed by standard deviation is presented. The 2-DE profiles obtained for sweet orange scion bark of healthy, CSD-affected, and CSD-tolerant trees were compared to each other; 2-DE profiles of Rangpur lime rootstock bark from the three treatments (healthy, CSD-affected, and CSD-tolerant) were also compared.

In-gel protein digestion. Down-regulated proteins (spots numbered in Result section) were manually excised with pipette tips (cut according to the spot size) and distained in $300 \mu \mathrm{l}$ of $50 \mathrm{mM} \mathrm{NH} \mathrm{HCO}_{3}, 50 \% \mathrm{ACN}$, dehydrated with $50 \mu \mathrm{l}$ of $\mathrm{ACN}$ and dried in a vacuum centrifuge. Twenty microliters of a trypsin solution $\left(20 \mu \mathrm{g} \mathrm{ml}^{-1}\right.$ in $\left.50 \mathrm{mM} \mathrm{NH} \mathrm{HCO}_{3}, 5 \mathrm{mM} \mathrm{CaCl}_{2}\right)$ was added (400 ng of trypsin) and digestion was carried out at $37^{\circ} \mathrm{C}$ for $22 \mathrm{~h}$ under gentle shaking. After the gel pieces were spun down, the supernatant was transferred to another tube, and the gel was extracted twice with $50 \mu \mathrm{l}$ of a solution containing $60 \% \mathrm{ACN}$ and $1 \%$ TFA (vol/vol) (44). After vortexing for $3 \mathrm{~min}$ at low speed, supernatants were collected, pooled, and desalted in a labmade zip tip. A piece of glass wool was compacted at the bottom of a pipette tip $(200 \mu \mathrm{l})$, and $100 \mu \mathrm{l}$ of a suspension of C-18 particles (30 to $65 \mu \mathrm{m}$ ) in isopropyl alcohol at $100 \mathrm{mg} \mathrm{ml}^{-1}$ was passed through the tip. The desalting process was initiated by conditioning the C-18 with $200 \mu \mathrm{l}$ of methanol followed by $200 \mu \mathrm{l}$ of $0.5 \%$ TFA. Samples were applied and the salt was washed out by passing $200 \mu \mathrm{l}$ of $0.5 \%$ TFA through the tip. Elution of peptides was carried out with an $80 \%$ ACN/1\% TFA solution; the volume of the extracted peptides was then reduced to 5 to $10 \mu \mathrm{l}$ by centrifugal evaporation.

MALDI-TOF-TOF and database query. For each protein spot, $1 \mathrm{ml}$ of the digested protein solution was mixed with $1 \mu \mathrm{l}$ of an ACN solution containing $5 \mathrm{mg} \mathrm{ml}^{-1} \alpha$-cyano-4-hydroxycinnamic acid, and $0.5 \mu \mathrm{l}$ was spotted in a 192-well MALDI plate, dried and analyzed in a mass spectrometer (4700 Proteomics Discovery System, Applied Biosystems, Foster City, CA). The laser power (Nd:Yag - $355 \mathrm{~nm}$ ) was adjusted to produce a better signal for both MS and MS/MS experiments. PMF of singly charged peptide ions (21) was collected from monoisotopic peaks falling in the $m / z$ range from 980 to $4,000 \mathrm{Da}$ with a resolution of about 13,000 and mass accuracy better than $15 \mathrm{ppm}$. The resulting mass spectrum of the five most intense peptides (MS/MS) was obtained over the mass range from 20 up to the mass of the parent ion, with a resolution and mass accuracy of about 2,000 and 50, respectively. The reflectron mode was used in all analyses. After
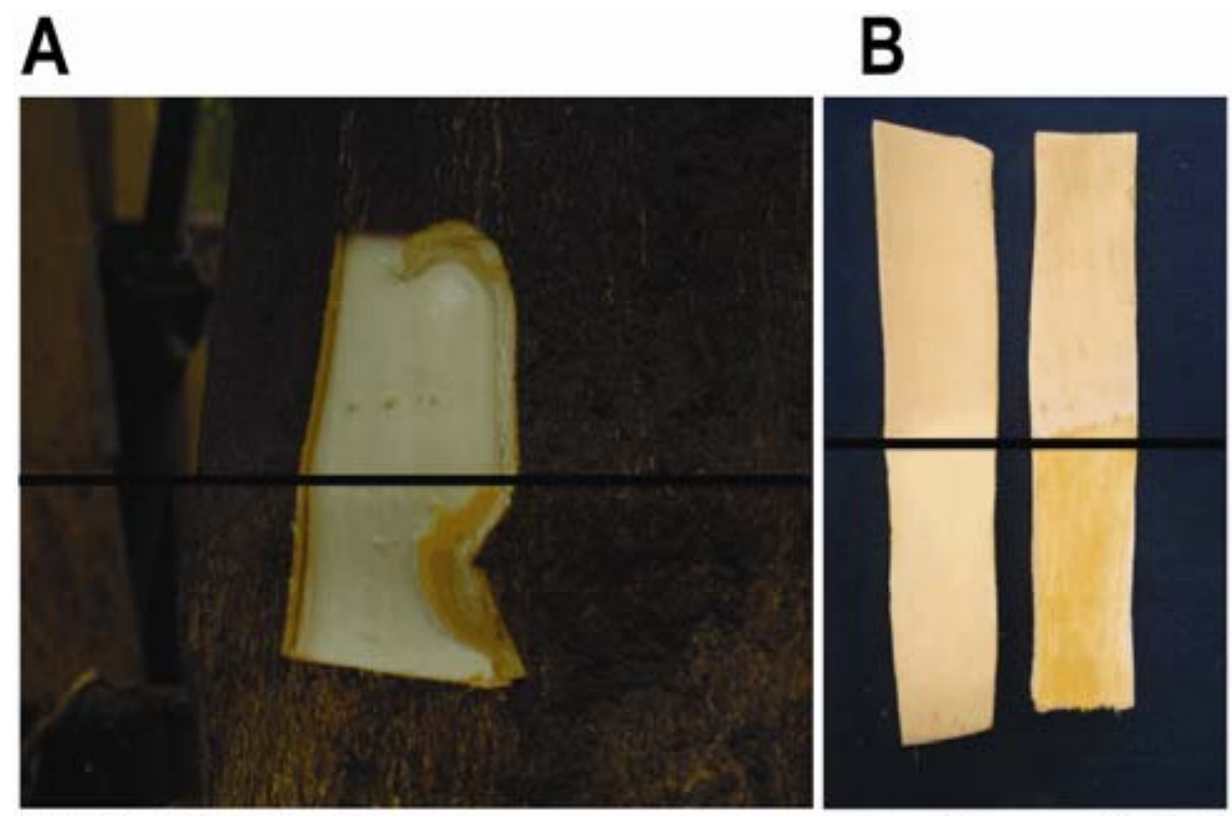

\section{CSD-Affected}

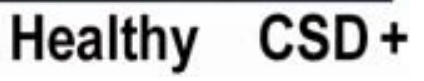

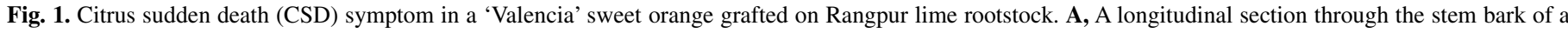

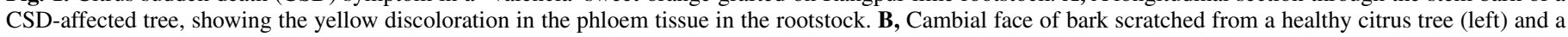
CSD-affected (right). The black line indicates the union between the scion and rootstock.

TABLE 1. Description of samples, organs, location, and disease status

\begin{tabular}{|c|c|c|c|c|c|}
\hline Citrus tree (scion/rootstock) & Taxonomic origin & Organ sampled & Location & $\begin{array}{l}\text { Citrus sudden death } \\
\text { (CSD) epidemics }\end{array}$ & CSD status grove \\
\hline Sweet orange/Rangpur lime & C. sinensis/C. limonia & Scion bark/rootstock bark & Gavião Peixoto, SP & Free & Healthy \\
\hline Sweet orange/Rangpur lime & C. sinensis/C. limonia & Scion bark/rootstock bark & Frutal, MG & Endemic & $\begin{array}{l}\text { CSD-affected (symptomatic } \\
\text { and symptomless) }\end{array}$ \\
\hline Tahiti lime/Rangpur lime & C. latifolia/C. limonia & Rootstock bark & Prata, MG & Endemic & CSD-tolerant (healthy) \\
\hline $\begin{array}{l}\text { Sweet orange/Cleopatra } \\
\text { mandarin }\end{array}$ & C. latifolia/C. reshni & Scion bark & Prata, MG & Endemic & CSD-tolerant (healthy) \\
\hline
\end{tabular}


the analyses, the data from each spot (MS and MS/MS) were exported in a text file format. The algorithm used for the sequence database search was the MASCOT MS/MS Ion Search version 2.0 (32), against the National Center for Biotechnology Information (NCBI) all entries database using the following parameters: missed cleavage $=1$, peptide mass tolerance $=0.1 \mathrm{Da}$, and MS/MS mass tolerance $=0.3 \mathrm{Da}$ (33). Carbamidomethylcysteine was set as a fixed modification since the sulfhydryl groups of cysteine residues react with IAA. Methionine oxidation was evaluated as a variable modification due to the oxidative environment of sample preparation.

\section{RESULTS}

The RAPD profiles confirmed that all analyzed rootstock samples were Rangpur lime and Cleopatra mandarin (9), as indicated by the farm managers. Scions were identified according to their morphologic phenotype since no molecular markers for sweet orange varieties were available.

The yield of total protein extraction was about $3.2 \%$ from fresh bark tissue. Proteins with pI values ranging from 3.27 to 9.97 and MW ranging from 7.27 to more than $100 \mathrm{kDa}$ were resolved. These values are consistent with the theoretical range expected for 10 to $12.5 \%$ polyacrylamide gels. In addition, only a few spots over $100 \mathrm{kDa}$ were resolved, which is also in agreement with the limited range of resolution of the IPG strips used for IEF.

IPG strips 3 to 10 were employed to compare CSD-affected, healthy, and CSD-tolerant patterns of proteins extracted from scions and rootstocks. Figure 2 shows the 2-DE maps of proteins from both the scions and the rootstocks from CSD-affected, healthy, and CSD-tolerant trees. All 2-DE gels showed a broad distribution of spots in a pI range from 3.2 to 9.45 and a mass range of 8 to $127 \mathrm{kDa}$. There was a remarkable difference between the 2-DE patterns of healthy and diseased plants, indicating that the composition of proteins of the rootstock bark from plants affected by CSD is altered (Fig. 2D to F). Similar, but less pronounced, differences were also observed in scion bark (mainly in the $20 \mathrm{kDa}$ region) (Fig. 2A to C). In addition, the protein pattern obtained for CSD-tolerant plants was consistent with the pattern of healthy plants; this is expected since the control plants are tolerant to CSD disease. Considering the intrinsic biological variability among plants under natural conditions, in which citrus scions are clonally propagated from buds, versus citrus rootstocks, which are obtained from seeds, the pattern exhibited a high level of reproducibility given that five samples were evaluated for each treatment.

This comparative proteomic analysis allowed us to conclude that there was a strong difference in the levels of specific proteins, especially in the two regions where the differences in the levels of proteins were remarkable: such differences are more pronounced in rootstock than in scion. Taking this previous result, we preceded with rootstock bark samples for further analysis. The expression level of a set of proteins with pIs between 6.1 and 9.6 and an MW of about $20 \mathrm{kDa}$ in CSD-affected plants (Fig. 2A and D) was lower than in healthy plants (Fig. 2B and E). CSD-tolerant samples (Fig. 2C and F) showed relative volumes that were slightly higher than healthy one, although this difference is not significant, which indicates that the observed changes between
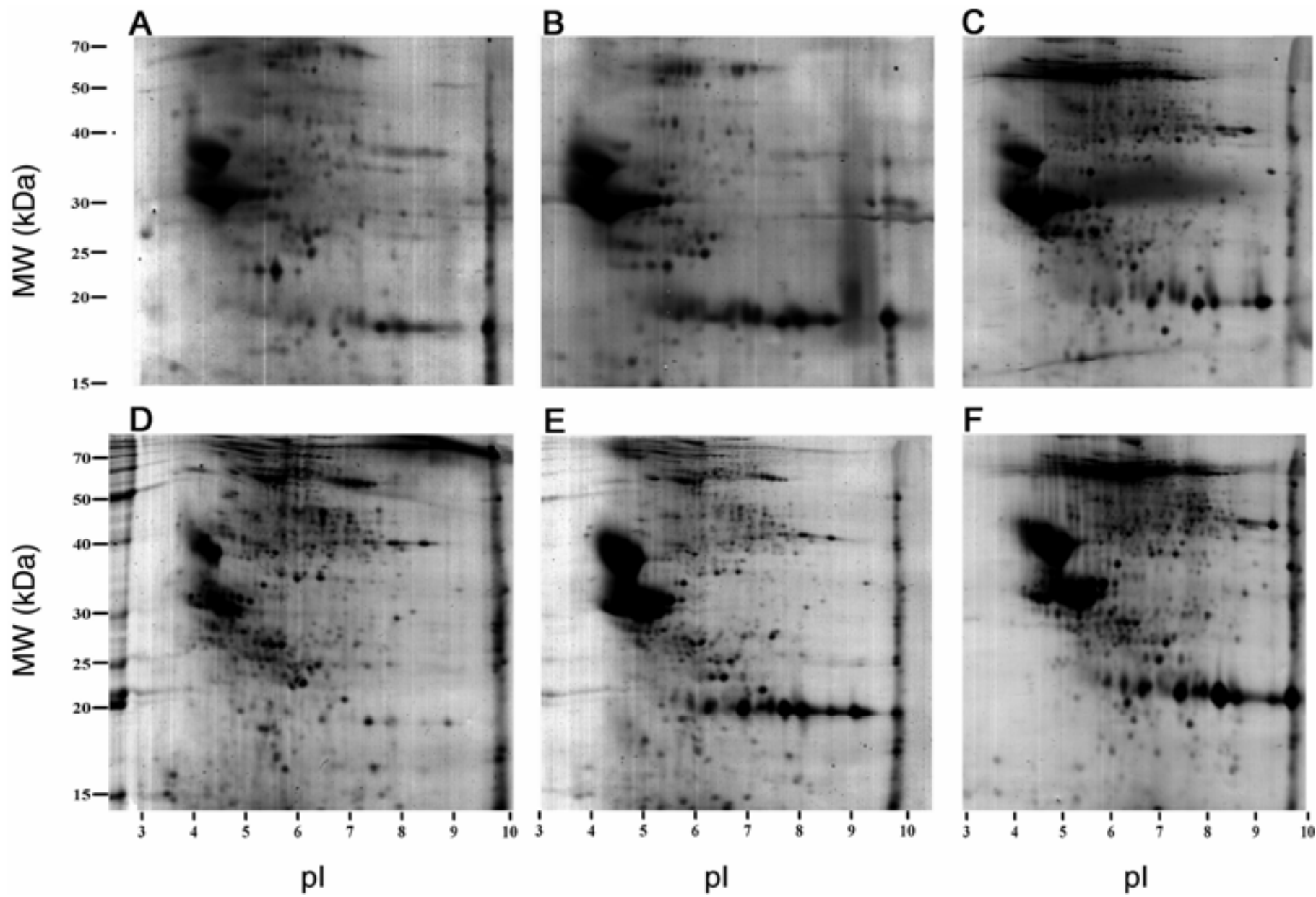

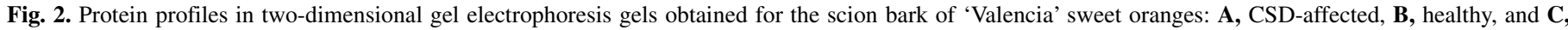

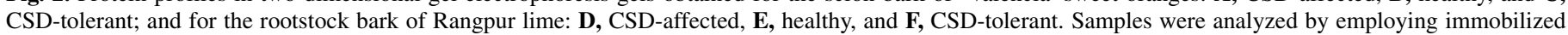
$\mathrm{pH}$ gradient strips, pH 3 to 10 , and $12.5 \%$ sodium dodecyl sulfate-polyacrylamide gel electrophoresis. 
healthy and CSD-affected plants are related to the diseased status of the samples and should not be attributed to the environment (Fig. 3). It is also important to note that CSD-tolerant trees are a different combination of scion and rootstock than Sweet orange on Rangpur lime (Table 1). The effect of different scion-rootstock combinations on protein composition is unknown. Figure 2 corresponds to the most representative gel ( $\mathrm{pI}$ from 3 to 10) from each treatment, and a detailed section of a representative gel from each treatment is shown in Figure 3.

When analyzing rootstock profiles, the comparison of the relative volume of nine selected spots in Figure 3 indicates that CSDaffected plants have a reduced content of such proteins. Although the difference is visually striking, when measuring relative spot volume, spots 6,7 , and 9 have a pronounced reduction in expression in CSD-affected bark; spots 1, 2, and 4 have lower means in CSD-affected plants, but overlapping standard deviation with healthy plants. Spots 3,5 , and 8 have the same mean value between healthy and diseased plants (Fig. 3).
The level of proteins with pI values ranging from 4.5 to 5.2 and with MW from 28 to $40 \mathrm{kDa}$ in CSD-affected plants was lower than in healthy samples (Fig. 4). Such alterations were more pronounced in barks from rootstocks than from scions (Fig. 2). In order to better evaluate the number of spots in which the proteins were down-regulated in CSD-affected plants, we performed the IEF step with a narrow $\mathrm{pH}$ range between 4 and 7 , aiming to achieve better resolution of the acidic proteins extracted from rootstocks (Fig. 4). This approach proved to be essential in order to resolve proteins in the 4.5 to $5.2 \mathrm{pI}$ range. As stated above, the differences between healthy and CSD-affected protein spots were remarkable, and we clearly detected 13 spots in the 28 to $32 \mathrm{kDa}$ region (Fig. 5). Spots 2 to 6 and 8 had a significantly lower spot volume in CSD-affected bark, whereas the remaining spots contained similar amounts of protein in healthy and CSD-affected plants. Figure 4 corresponds to the most representative gel (pI from 4 to 7) from each treatment, and a detailed section of a representative gel from each treatment is shown in Figure 5.
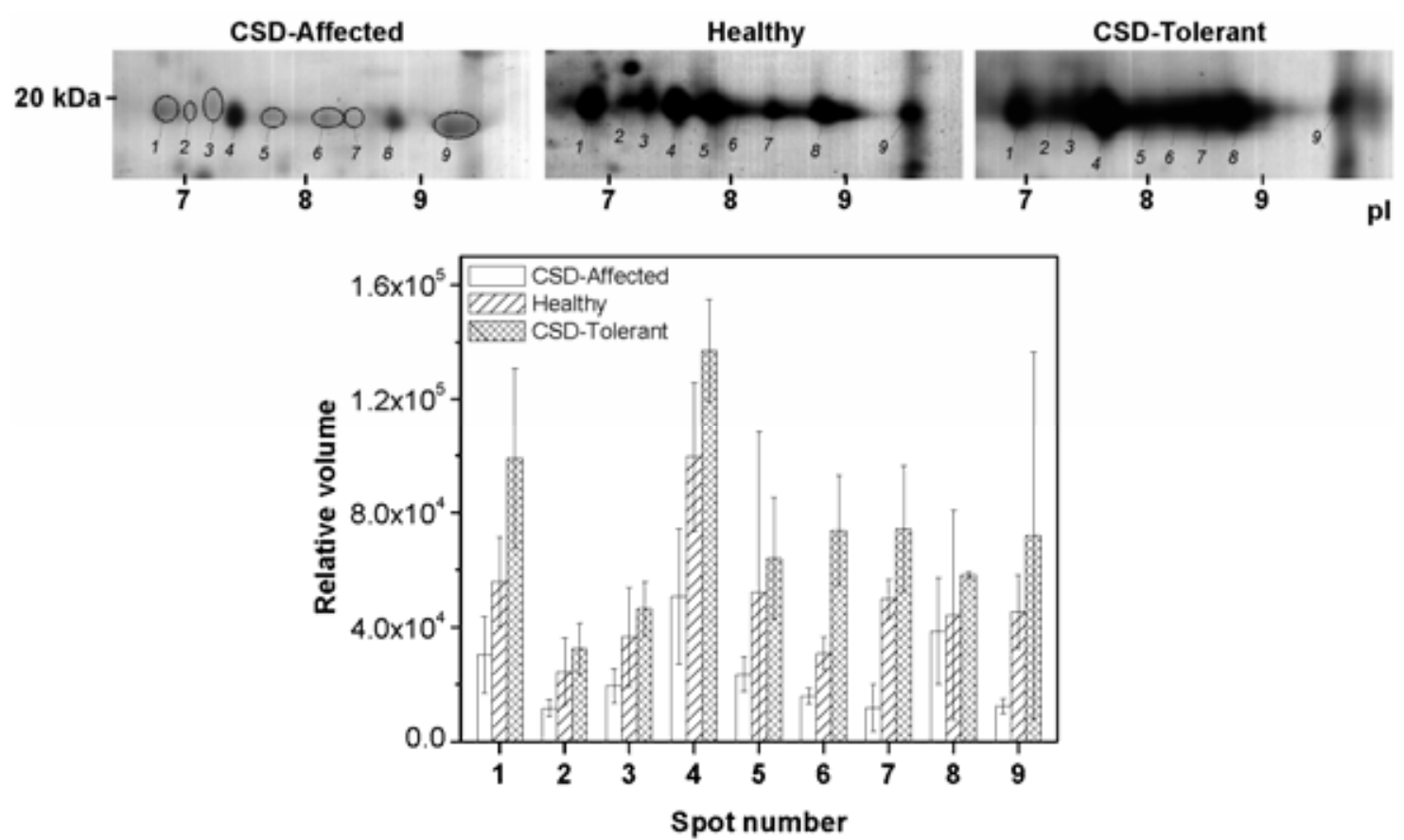

Fig. 3. Enlargement of a specific region of the two-dimensional gel electrophoresis gels/immobilized pH gradient to 10 from Figure 2, for citrus sudden death (CSD)-affected, healthy, and CSD-tolerant rootstock bark. The enlarged region shows proteins with pls ranging from 6.1 to 9.6 and molecular weight around $20 \mathrm{kDa}$, and 9 of these spots. The graph illustrates the relative spot volume for each spot in the treatments and data are presented as the average of five replicates with standard deviations.
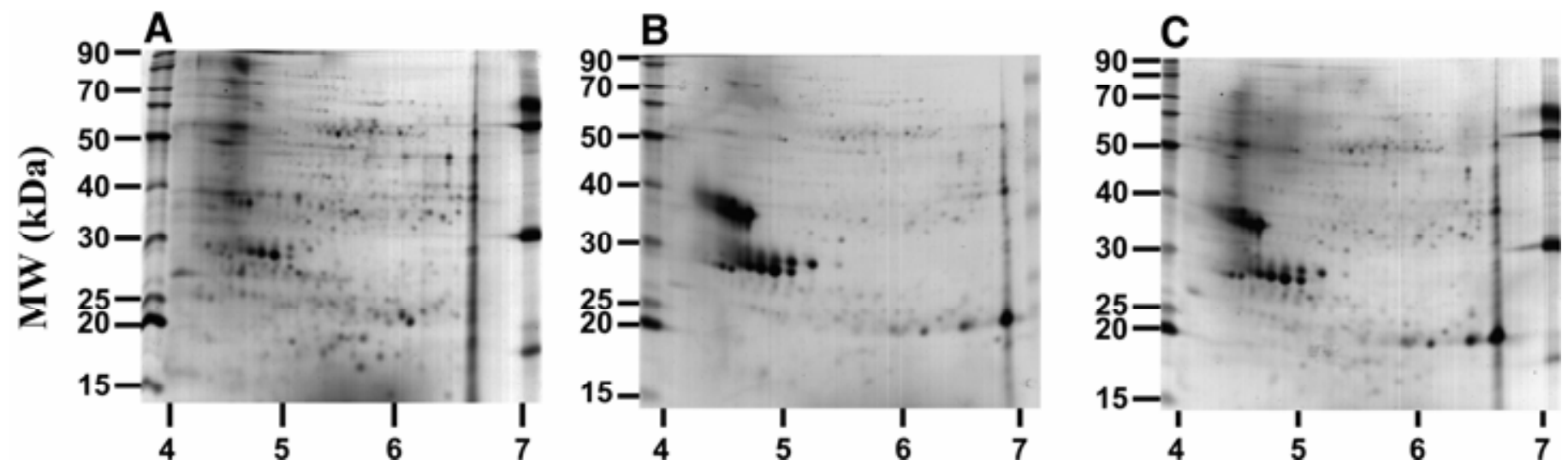

Fig. 4. High-resolution protein profiles by two-dimensional gel electrophoresis gels from the rootstock bark tissue of Rangpur lime: A, citrus sudden death (CSD)affected, B, healthy, and C, CSD-tolerant. Samples were analyzed by employing immobilized pH gradient strips pH 4 to 7 and $10 \%$ Tris-tricine polyacrylamide gel electrophoresis. 
To validate our data, we analyzed the rootstock bark from five symptomless plants that were collected in the same plot as the affected plants (i.e., in the CSD endemic region). Although three out of five plants showed patterns typical of healthy samples (as in Fig. 2E), two plants showed a protein pattern characteristic of CSD-affected plants (as in Fig. 2D). This indicates that the alteration in the protein profile is a biochemical alteration that occurs before a canopy symptom becomes conspicuous (data not shown); such a pattern is not observed for healthy tree bark collected where CSD is not present.

The two sets of differentially expressed protein (spots numbered in Figures 3 and 5) were submitted to MALDI-TOF/TOF analysis and MS/MS spectra comparison. Proteins highlighted in Figure 3 (spots 1 to 9) were identified by MS/MS as putative miraculin-like protein (accession ABL67650), which are homologs of the Kunitz family of proteinase inhibitors. These proteins had scores up to 189 , which is well above the cut-off value for identification (32). Four peptides (DYYLVSAIR, ALAVVLVPGNER, TSIINEDVDLNVR, and NELCPLDVVQLSSDSER) were sequenced by tracking their $y$-series of ions, yielding an overall coverage of $28 \%$ of the amino acid sequence from protein ABL67650. In addition, the $\mathrm{pI}$ and MW values of the miraculin-like protein ABL67650 (pI 8.18 and MW of 23610) are in accordance with the experimental 2-DE data ( $\mathrm{pI}$ ranging from 6.1 to 9.6 and MW around $20 \mathrm{kDa}$ ). Since different spots with different $\mathrm{pI}$ values and nearly the same MW were identified as the same protein (putative miraculin-like), this protein either undergoes PTM or the spots represent expression of a multigene family.

Spots 2 through 13 (Fig. 5), corresponding to the set of proteins with pIs ranging from 4.5 to 5.2 and $\mathrm{MW}$ around $30 \mathrm{kDa}$, were identified as chitinases by MS/MS (accession T10106). These proteins displayed scores up to 116, allowing a secure identification (32). The pI 5.06 and MW of 32459 of chitinase T10106 are in good agreement with experimental 2-DE data, namely, a pI ranging from 4.5 to 5.2 and an $\mathrm{MW}$ around $30 \mathrm{kDa}$. Figure 6 shows the PMF and the MS/MS spectrum of a singly-charged protonated molecule of $m / z, 1,177.6$ of the identified chitinase. In this case, the peptide amino acid sequence (IGFFTTFC*GK) was completely determined by tracking the $y$-series of ions. The other two peptides were correctly identified (GPIQLSWNYNYLR and EMFDDLLEYR+oxidation(M)), and the overall coverage for chitinase was equal to $11.3 \%$. Either chitinase isoforms or chitinases with PTM were present since protein spots with different pI values were identified as the same protein.

Protein sequencing by mass spectrometry (de novo sequencing) is an emerging technology that adds a new approach to the characterization of proteins from citrus and their hybrids.

\section{DISCUSSION}

A comparison of protein profiles between healthy and CSDaffected bark allowed us to perform the first biochemical characterization of citrus responses to CSD disease. The expression of two classes of pathogenesis-related proteins (PR-proteins), chitinases, and proteinase inhibitors, is severely down-regulated in diseased rootstock bark.

To our knowledge, only a single study related to the proteomic study of woody tree bark tissue has been published (14), in addition to a few papers dealing with proteins from green and aged plant tissues $(20,48)$. Comprehensive protein extraction from woody plant tissues is difficult because rupture of the cell wall is required, but the proteins must be intact in solution in the presence of proteases, phenolic compounds, and other secondary metabolites. Working with bark tissues may pose additional problems due to tissue age and the consequent cell rigidity caused by lignification. However, the protocol employed here was satisfactory in extracting proteins over a wide range of $\mathrm{pI}$ and $\mathrm{MW}$ and was thus proven to be useful for proteomics studies.

All citrus plants in Brazil are infected with the CTV, and the impact of such an infection at the protein level has not yet been evaluated in citrus trees. If, in fact, a new virus (CSDaV), a new strain of CTV, or both are the cause of CSD $(1,25)$, a combination of several agents may interact to lead to CSD:CTV, CSDaV, and scion-rootstock combination. Due to the limited information about the etiology of $\operatorname{CSD}(1,11,25,38)$, we chose to use tree symptoms as the criterion for sample collection because it is a well-reported characteristic $(1,3,11,16,25,26,38,49)$.
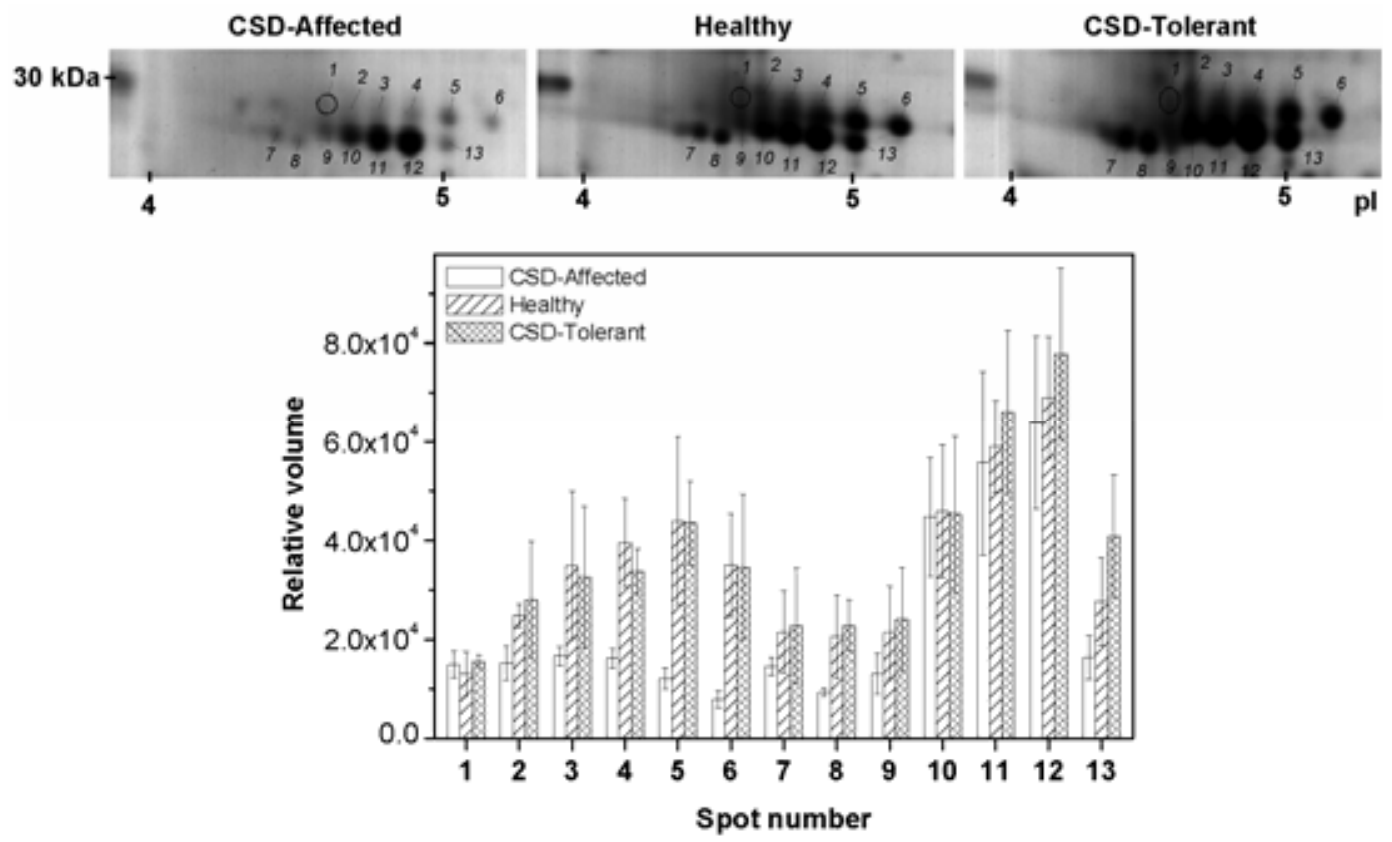

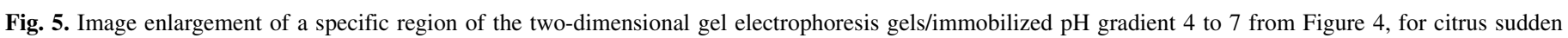

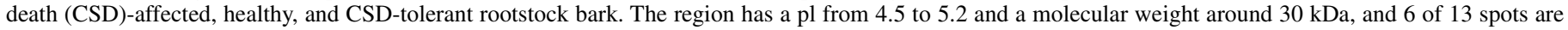

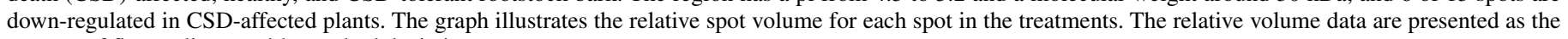
average of five replicates with standard deviations. 
It is clear that there are consistent modifications in protein profiles of healthy and diseased plants. Such alterations follow a distinct change in the structure of secondary phloem in the bark of Rangpur lime rootstock (38). Measuring spot volume is a useful way to compare spots from replicates since natural variation may occur among plants. Analysis of protein profiles allowed us to detect protein expression alterations more easily in rootstock barks than in scion barks.

Cooper et al. (10) identified a protein spot that corresponded to the coat protein of tobacco mosaic virus; it was present only in 2-DE gels from infected Nicotiana tabacum, indicating a high accumulation of viral particles in that host (10). In the case of CSD, no differential spot for infected bark was detected in the MW and pI range corresponding to coat proteins of CTV or CSDaV. This indicates the low titer achieved by these viruses in the CSD-affected citrus (25).

Plant protease inhibitors are PR-proteins belonging to family 6 . These proteins are both developmentally regulated and induced in response to insect and pathogen attack. Such proteins are thought to be involved in protein turnover (house-keeping function), blockage of the activity of digestive enzymes, and many are active against insect herbivores and pathogens. Such proteins are usually encoded by multigene families (40). In citrus, cDNAs of putative protease inhibitors have been described for $C$. paradisi flavedo (43). In $C$. sinensis, upon leafhopper herbivory, putative protease inhibitors as well as chitinase genes were up-regulated (29). In $C$. jambhiri, two cDNAs encoding miraculin-like proteins were detected in fruits but not in leaves (47).

Plant chitinases are well-known PR-proteins, belonging to PRprotein families PR-3, PR-4, PR-8, and PR-11 (22); together with $\beta$-glucanases, they are induced upon pathogen attack (45). PRproteins of several classes have been identified by MS in tomatoFusarium oxysporum interaction (36), tomato fruits infected with TMV (7), and rice leaves infected with Magnaporthe grisea (23).
Chitinases are markers of disease resistance and systemic acquired resistance (39) due to their ability to break down fungal cell walls by hydrolysis of $N$-acetyl- $\beta$-D-glucosamine $1,4-\beta$ linkages (42). Some chitinases are also able to carry out hydrolysis of 1,4- $\beta$-linkages between $N$-acetylmuramic acid and $N$ acetyl-D-glucosamine residues in peptidoglycans, through action as lysozymes (4) or through their ability to deacetylate chitins, thereby acting as chitosanases $(27,31)$. Moreover, as part of the multicomplex defense reaction of plants, the roles of chitinases are not restricted to preventing pathogen growth since they are constitutively expressed in several tissues, such as healthy floral organs. However, not all proteins ascribed as chitinases exhibit chitinase/chitinolytic activity (22).

Several citrus chitinases have been cloned (35) or purified $(28,31)$. In grapefruit flavedo $(C$. paradisi), both chitinases and $\beta$ 1,3-glucanases were present as acidic and basic forms (28). In grapefruits, UV irradiation, and wounding induced expression of chitinases; whereas the level of $\beta$-1,3-glucanase remained unchanged (34). While the expression of chitinase was demonstrated at the mRNA level for citrus bark chitinases (30), our results are the first to report expression of chitinases at the protein level in the bark of Rangpur lime rootstock and sweet orange scion. Furthermore, to our knowledge, expression of proteinase inhibitor proteins in such tissues has not yet been reported in citrus. Citrus trees are perennial woody plants that have to handle pathogen and insect attacks over their entire life span. The constitutive expression of a defense mechanism in plants represents a way to overcome such attacks; thus, some PR-proteins may be constitutively expressed, such as chitinases and $\beta$-1,3-glucanases (15). Both classes of proteins identified in this study (Figs. 3 and 5) are among the most abundant in citrus bark.

In poplar, chitinases and the Kunitz trypsin inhibitors were among the most abundant wound-induced ESTs (8), indicating up-regulation of the defense reaction. In Prunus armeniaca, the
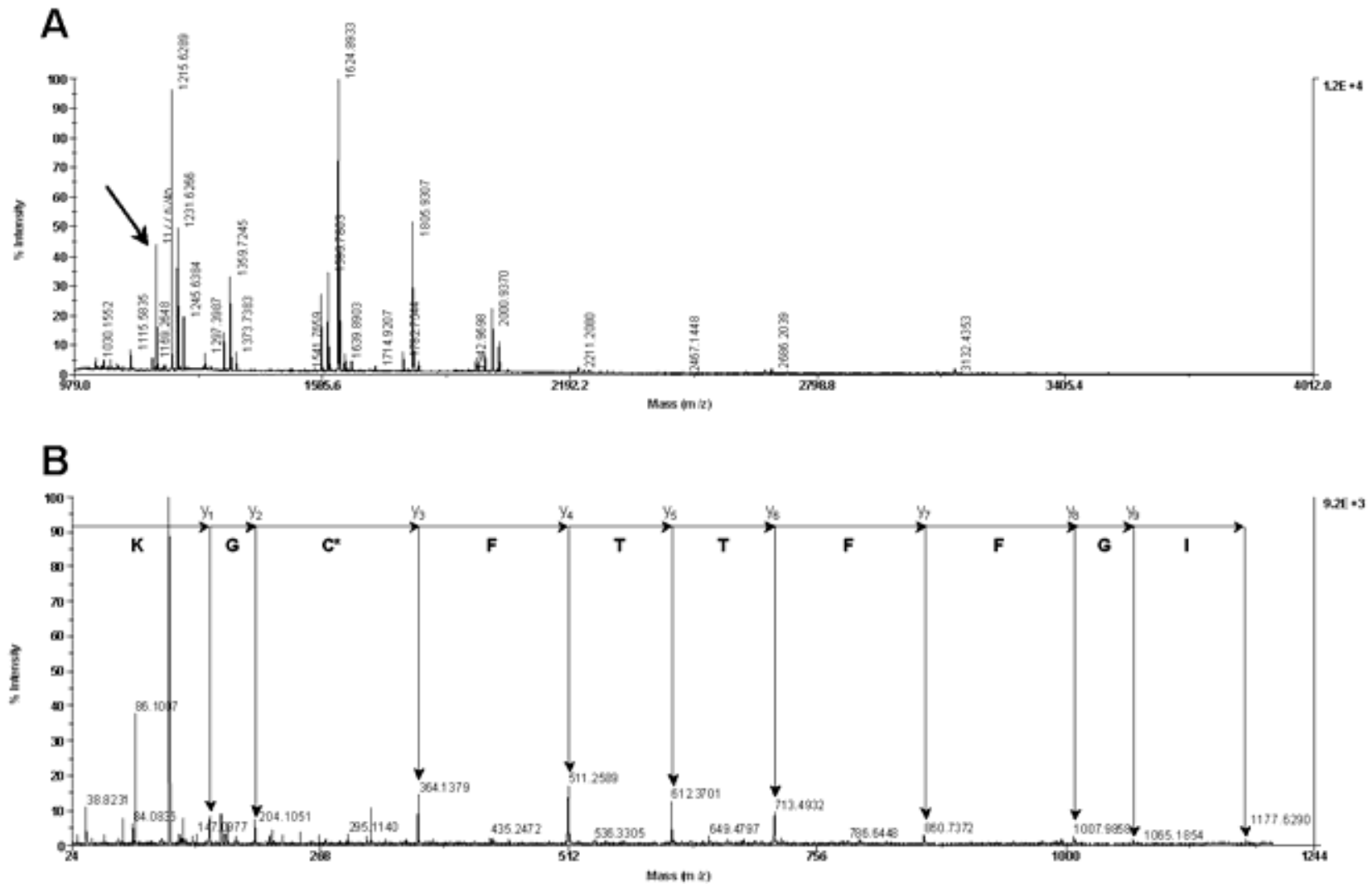

Fig. 6. Matrix-assisted laser desorption and ionization coupled with tandem time of flight mass spectrometry (MALDI-TOF-TOF) analysis of spot 12 (Figure 5 , healthy sample). A, Peptide mass fingerprint (PMF), B, tandem MS (MS/MS) spectrum of tryptic peptide $[\mathrm{M}+\mathrm{H}]^{+} ; m / z, 1,177.6$ (indicated by an arrow in A), with the deduced amino acid sequence. $C^{*}$ represents the carbamidomethylcysteine. 
Plum pox virus (PPV) represses the expression of a putative class III chitinase at the mRNA level in infected plants of the partially resistant genotype Goldrich, while it is expressed in the susceptible cv. Screara (13). In CSD-affected plants, down-regulation of such defense responses was clearly shown. However, we were unable to find any previous study addressing chitinase suppression at the protein level in a plant-pathogen interaction in woody perennial plants.

Protein identification by MS/MS, along with previous reports $(31,28)$, led us to assume that citrus bark has a large number of chitinase isoforms since PR-proteins might be expressed as isoforms (15). Eight acidic isoforms (31) and seven basic chitinases (27) were purified from cell cultures of $C$. sinensis cv. Valencia. The reported acidic chitinase isoforms with MW between 26 and $37.4 \mathrm{kDa}$ and pIs from 4.5 to 5.4 (31) are consistent with our data (Fig. 3), and they may represent PTM, as has been previously proposed (31). Previous studies utilized cell cultures of Citrus spp. $(27,31)$ or grapefruit flavedo (28). 2-DE enabled us to demonstrate expression of chitinases and proteinase-inhibitors in citrus bark but also revealed several isoforms in the bark tissue of Rangpur lime rootstock and 'Valencia' scion adult trees.

Because CSD is a disease with unknown etiology, probably viral $(1,25,38)$, the pattern of chitinase and proteinase inhibitor suppression in CSD-affected plants is remarkable. Our data show that, in CSD-affected bark, defense reactions (i.e., expression of chitinases and miraculin-like proteins) have been suppressed. Such an effect was not observed in tolerant scion-rootstock combinations, even though such plants were growing in the presence of pathogen pressure (Figs. 2 to 5); nor ever in healthy plants from outside the epidemic.

This is the first report of a proteomic approach to studying citrus trees, and the results are remarkable since the observation of chitinase as well as the suppression of a miraculin-like protein/Kunitz trypsin inhibitor highlights the suppression of PRproteins in citrus plants with CSD. Once these PR-proteins are down-regulated in CSD-affected plants, it is possible that these plants become more susceptible to infection by secondary pathogens such as fungi since profuse root rot is observed in affected plants. The roles of such proteins in citrus physiology have not yet been assessed.

Down-regulation of the identified proteins was stronger in Rangpur lime bark than in Sweet orange bark, indicating that this is a more sensitive region than the scion bark, a further indication of the incompatibility of Rangpur lime with scion (38) in the presence of the pathogen. Furthermore, a difference in downregulation between rootstock and scion indicate this deregulation to be a specific response of citrus to CSD and does not represent a declining response due to root rot caused by CSD. The applicability of such results can be seen by the analysis of five symptomless bark samples collected in an affected grove. The protein profile of two samples was identical to that of CSD-affected plants, while the three remaining were healthy-like profiles. This is also an indication that biochemical alterations precede the yellowing of bark, as is the case for the anatomical alterations (38).

Understanding the molecular events that lead to diseases such as CSD is essential since the citrus industry is based on the low genetic variability of clonally multiplied scion citrus and the restricted availability of rootstock. Losing the predominant rootstock Rangpur lime to disease is a key concern for both the growers and the citrus industry in Brazil. Downregulated proteins can be useful as negative markers to identify CSD affected trees. Our next steps will be aimed toward the evaluation of mRNA expression levels and enzyme activities of such groups of PR-proteins at different levels of CSD symptoms and relate this study to the occurrence of $\mathrm{CSDaV}$ in affected plants.

\section{ACKNOWLEDGMENTS}

We thank the Brazilian Synchrotron Light Laboratory (LNLS) for the use of Mass Spectrometry Laboratory under proposal MAS-3213 and A. R. A. Nogueira (CPPSE - Embrapa) for the use of the Freezing Mill. We thank A. Sanches for helping collecting samples in the field, M. de A. Santos for technical assistance, and D. C. Teixeira and E. Martins for RAPD protocol. M. D. Cantú acknowledges financial support and fellowship from FAPESP.

\section{LITERATURE CITED}

1. Bassanezi, R. B., Bergamin Filho, A., Amorim, L., Gimenes-Fernandes, N., Gottwald, T. R., and Bové, J. M. 2003. Spatial and temporal analyses of citrus sudden death as a tool to generate hypotheses concerning its etiology. Phytopathology 93:502-512.

2. Bassanezi, R. B., Gimenes-Fernandes, N., and Massari, C. A. 2006. Progresso da Morte Subita dos Citrus no estado de Sao Paulo no período 2002-2005. Laranja 27:13-29.

3. Bassanezi, R. B., Montesino, L. H., Sanches, A. L., Spósito, M. B., Stucchi, E. S., and Barbosa, J. C. 2007. Effect of citrus sudden death on yield and quality of sweet orange cultivars in Brazil. Plant Dis. 91:14071412.

4. Bernasconi, P., Locher, R., Pilet, P. E., Jollès, J., and Jollès, P. 1987. Purification and n-terminal amino-acid-sequence of a basic lysozyme from Parthenocissus quinquifolia cultured in vitro. Biochim. Biophys. Acta 915:254-260.

5. Bradford, M. M. 1976. Rapid and sensitive method for quantitation of microgram quantities of protein utilizing principle of protein-dye binding. Anal. Biochem. 72:248-254.

6. Candiano, G., Bruschi, M., Musante, L., Santucci, L., Ghiggeri, G. M., Carnemolla, B., Orecchia, P., Zardi, L., and Righetti, P. G. 2004. Blue silver: A very sensitive colloidal Coomassie G-250 staining for proteome analysis. Electrophoresis 25:1327-1333.

7. Casado-Vela, J., Sellés, S., and Martínez, R. B. 2006. Proteomic analysis of tobacco mosaic virus-infected tomato (Lycopersicon esculentum M.) fruits and detection of viral coat protein. Proteomics 6:S196-S206.

8. Christopher, M. E., Miranda, M., Major, I. T., and Constabel, C. P. 2004. Gene expression profiling of systemically wound-induced defenses in hybrid poplar. Planta 219:936-947.

9. Coletta Filho, H. D., Pompeu, J., Jr., and Machado, M. A. 2004. Certificação genética de porta-enxertos de citros: Dados de 2003. Laranja 25:171-178.

10. Cooper, B., Eckert, D., Andon, N. L., Yates, J. R., and Haynes, P. A. 2003. Investigative proteomics: Identification of an unknown plant virus from infected plants using mass spectrometry. J. Am. Soc. Mass Spectrom. 14:736-741.

11. Derrick, K. S., Beretta, M. J., Barthe, G. A., Kayim, M., and Harakava, R. 2003. Identification of strains of Citrus tristeza virus by subtraction hybridization. Plant Dis. 87:1355-1359.

12. Doyle, J. J., and Doyle, J. L. 1987. A rapid DNA isolation procedure for small quantities of fresh leaf tissue. Focus 12:13-15.

13. Escalettes, V. S. L., Hullot, C., Wawrzy'nczak, D., Mathieu, E., Eyquard, J. P., Le Gall, O., and Decroocq, V. 2006. Plum pox virus induces differential gene expression in the partially resistant stone fruit tree Prunus armeniaca cv. Goldrich. Gene 374:96-103.

14. Faurobert, M. 1997. Application of two-dimensional gel electrophoresis to Prunus armeniaca leaf and bark tissues. Electrophoresis 18:170-173.

15. Fink, W., Liefland, M., and Mendgen, K. 1988. Chitinases and beta-1,3glucanases in the apoplastic compartment of oat leaves (Avena sativa L.). Plant Physiol. 88:270-275.

16. Gimenes-Fernandes, N., and Bassanezi, R. B. 2001. Doença de causa desconhecida afeta pomares cítricos no norte de São Paulo e sul do Triângulo Mineiro. Summa Phytopathol. 27:93.

17. Gomes, C. P. C., Nagata, T., Jesus, W. C., Jr., Borges Neto, C. R., Pappas, G. J., Jr., and Martin, D. P. 2008. Genetic variation and recombination of RdRp and HSP 70h genes of Citrus tristeza virus isolates from orange trees showing symptoms of citrus sudden death disease. Virol. J. 5:9 doi:10.1186/1743-422X-5-9.

18. Görg, A., Weiss, W., and Dunn, M. J. 2004. Current two-dimensional electrophoresis technology for proteomics. Proteomics 4:3665-3685.

19. Herron, C. M, da Graça, B. M., da Graça, J. V., Shatters, J. V., Jr., and Mirkov, T. E. 2002. A low titer RNA entity in a Citrus tristeza virusinfected Mexican Lime plant with similarities to Oat blue dwarf virus and Grapevine fleck virus. (Abstr.) Phytopathology 92(suppl.):S36.

20. Islam, N., Lonsdale, M., Upadhyaya, N. M., Higgins, T. J., Hirano, H., and Akkurst, R. 2004. Protein extraction from mature rice leaves for twodimensional gel electrophoresis and its application in proteome analysis. Proteomics 4:1903-1908. 
21. Karas, M., Gluckmann, M., and Schafer, J. 2000. Ionization in matrixassisted laser desorption/ionization: Singly charged molecular ions are the lucky survivors. J. Mass Spectrom. 35:1-12.

22. Kasprzewska, A. 2003. Plant chitinases-Regulation and function. Cell. Mol. Biol. Lett. 8:809-824.

23. Kim, S. T., Kim, S. G., Hwang, D. H., Kang, S. Y., Kim, H. J., Lee, B. H., Lee, J. J., and Kang, K. Y. 2004. Proteomic analysis of pathogenresponsive proteins from rice leaves induced by rice blast fungus, Magnaporthe grisea. Proteomics 4:3569-3578.

24. Laemmli, U. K. 1970. Cleavage of structural proteins during assembly of head of bacteriophage-T4. Nature 227:680-685.

25. Maccheroni, W., Alegria, M. C., Greggio, C. C., Piazza, J. P., and Kamla, R. F., et al. 2005. Identification and genomic characterization of a new virus (Tymoviridae family) associated with citrus sudden death disease. J. Virol. 79:3028-3037.

26. Machado, M. A., Targon, M. L. P. N., Coletta-Filho, H. D., and Müller, G. W. 2004. Morte subita dos citros. Laranja 25:69-69.

27. Mayer, R. T., McCollum, T. G., Niedz, R. P., Hearn, C. J., McDonald, R. E., Berdis, E., and Doostar, H. 1996. Characterization of seven basic endochitinases isolated from cell cultures of Citrus sinensis (L.). Planta 200:289-295

28. McCollum, T. G., Doostdar, H., Mayer, R. T., and McDonald, R. E. 1997. Characterization of chitinases and beta-1,3-glucanases in grapefruit flavedo during fruit development. Physiol. Plantarum 99:486-494.

29. Morozuk, J., Hunnicutt, L. E., Cave, R. D., Hunter, W. B., and Bausher, M. G. 2006. Profiling transcriptional changes in Citrus sinensis (L.) Osbeck challenged by herbivory from the xylem-feeding leafhopper Homalodisca coagulate (Say) by cDNA macroarray analysis. Plant Sci. 170:1068-1080.

30. Nairn, C. J., Niedz, R. P., Hearn, C. J., Osswald, W. F., and Mayer, R. T. 1997. cDNA cloning and expression of a class II acidic chitinase from sweet orange. Biochim. Biophys. Acta Gene Struct. Express. 1351:22-26.

31. Osswald, W. F., Shapiro, J. P., Doostdar, H., MacDonald, R. E., Niedz, R. P., Nairn, C. J., Hearn, C. J., and Mayer, R. T. 1994. Identification and characterization of acidic hydrolases with chitinase and chitosanase activities from sweet orange callus-tissue. Plant Cell Physiol. 35:811-820.

32. Pappin, D. J. C., Hojrup, P., and Bleasby, A. J. 1993. Rapid identification of proteins by peptide-mass fingerprinting. Curr. Biol. 3:327-332.

33. Perkins, D. N., Pappin, D. J., Creasy, D. M., and Cottrell, J. S. 1999. Probability-based protein identification by searching sequence databases using mass spectrometry data. Electrophoresis 20:3551-3567.

34. Porat, R., Lers, A., Dori, S., Cohen, L., Weiss, B., Daus, A., Wilson, C. L., and Droby, S. 1999. Induction of chitinase and beta-1,3-endoglucanase proteins by UV irradiation and wounding in grapefruit peel tissue. Phytoparasitica 27:233-238.

35. Porat, R., Vinokur, V., Holland, D., McCollum, R. G., and Droby, S. 2001. Isolation of a citrus chitinase cDNA and characterization of its expression in response to elicitation of fruit pathogen resistance. J. Plant Physiol. 158:1585-1590.

36. Rep, M., Dekker, H. L., Vossen, J. H., de Boer, A. D., Houterman, P. M., Speijer, D., Back, J. W., de Koster, C. G., and Cornelissen, B. J. C. 2002.
Mass spectrometric identification of Isoforms of PR proteins in xylem sap of fungus-infected tomato. Plant Physiol. 130:904-917.

37. Rivas-Valencia, P., Loeza-Kuc, E., Mora-Aguilera, G., Febres, V., OchoaMartinez, D., Gutierrez-Espinosa, M. A., Jesús, W. C., Jr., Malvas, C. C., and Wulff, N. A. 2008. Population structure of citrus tristeza virus isolates and its association with citrus sudden death in Brazil. Agrociencia 42:8593.

38. Román, M. P., Cambra, M., Juárez, J., Moreno, P., Duran-Vila, N., Tanaka, F. A. O., Alves, E., Kitajima, E. W., Yamamoto, P. T., Bassanezi, R. B., Teixeira, D. C., Junior, W. C. J., Ayres, A. J., Gimenes-Fernandes, N., Rabenstein, F., Girotto, L. F., and Bové, J. M. 2004. Sudden death of citrus in Brazil: A graft-transmissible bud union disease. Plant Dis. 88:453-467.

39. Ryals, J. A., Neuenschwander, U. H., Willits, M. G., Molina, A., Steiner, H. Y., and Hunt, M. D. 1996. Systemic acquired resistance. Plant Cell 8:1809-1819.

40. Ryan, C. A. 1990. Protease inhibitors in plants: Genes for improving defenses against insects and pathogens. Annu. Rev. Phytopathol. 28:425449.

41. Schägger, H., and Vonjagow, G. 1987. Tricine sodium dodecyl-sulfate polyacrylamide-gel electrophoresis for the separation of proteins in the range from 1-kDa to 100-kDa. Anal. Biochem. 166:368-379.

42. Schlumbaum, A., Mauch, F., Vögeli, U., and Boller, T. 1986. Plant chitinases are potent inhibitors of fungal growth. Nature 324:365-36.

43. Shatters, R. G., Jr., Bausher, M. G., Hunter, W. B., Chaparro, J. X., Dang, P. M., Niedz, R. P., Mayer, R. T., McCollum, T. G., and Sinisterra, X. 2004. Putative protease inhibitor gene discovery and transcript profiling during fruit development and leaf damage in grapefruit (Citrus paradisi Macf.). Gene 326:77-86.

44. Shevchenko, A., Wilm, M., Vorm, O., and Mann, M. 1996. Mass spectrometric sequencing of proteins from silver stained polyacrylamide gels. Anal. Chem. 68:850-858.

45. Shimizu, T., Satoh, K., Kikuchi, S., and Omura, T. 2007. The repression of cell wall- and plantid-related genes and induction of defense-related genes in rice plants infected with Rice dwarf virus. Mol. Plant-Microbe Interact. 20:247-254.

46. Suckau, D., Resemann, A., Schuerenberg, M., Hufnagel, P., Franzen, J., and Holle, A. 2003. A novel MALDI LIFT-TOF/TOF mass spectrometer for proteomics. Anal. Bioanal. Chem. 376:952-965.

47. Tsukuda, S., Gomi, K., Yamamoto, H., and Akimitsu, K. 2006. Characterization of cDNAs encoding two distinct miraculin-like proteins and stress-related modulation of the corresponding mRNAs in Citrus jambhiri Lush. Plant Mol. Biol. 60:125-136.

48. Wang, W., Scali, M., Vignani, R., Spadafora, A., Sensi, E., Mazzuca, S., and Cresti, M. 2003. Protein extraction for two-dimensional electrophoresis from olive leaf, a plant tissue containing high levels of interfering compounds. Electrophoresis 24:2369-2375.

49. Yamamoto, P. T., Jesus, W. C. J., Bassanezi, R. B., Sanches, A. L., Ayres, A. J., Gimenes-Fernandes, N., and Bové, J. M. 2003. Transmission of the agent inducing symptoms of citrus sudden death by graft-inoculation under insect-proof conditions. Fitopatol. Bras. 28:S265. 